\title{
Emotional Changes after Divorce in Women
}

\author{
Nataša Rijavec Klobučar \\ University of Ljubljana, Slovenia
}

\begin{abstract}
Divorce has been rated as one of the most stressful life events, strongly impacting the lives of all family members (Amato 2000, 1274; Holmes and Rahe 1967). Research shows that the consequences of a divorce are negative as well as positive, affecting various aspects of the lives of those involved.

The article focuses on the experience of divorced women, especially on dealing with emotional changes after divorce as one of potential changes, and presents the results of qualitative study with female participants who had experienced divorce. Semi-structured interviews were conducted with 8 women who ranged in age from 31 to 48 .

The study's findings are similar to already existing findings about negative as well as positive changes after divorce. Women attribute different meanings to the experience of divorce, and in the period of adapting to a new life situation, when they part with a very important relationship and work on themselves to improve their lives, they face negative emotions as well as positive responses.
\end{abstract}

Keywords: divorce, consequences, emotional changes, women

1 The author acknowledges the financial support from the Slovenian Research Agency (project No. J5-6825). 


\section{Introduction}

Divorce is one of the most stressful and emotional events in the life of an individual facing transformation of their family system. Researchers (Amato 2000; Amato and Booth 1991; Clarke-Stewart and Brentano 2006) confirm its complex and long-term consequences in the lives of all family members, especially focusing on determining long-term effects on the development of children and adults, respectively. Divorce affects all family members, while the scope of consequences depends on various factors connected with the causes for and circumstances of divorce as parallel supportive factors which significantly help divorcees adapt to a new life situation (Amato 2003; Amato 2010; Wallerstein and Kelly 1996, 17). Several unsettling, uncomfortable and frightening feelings, thoughts and emotions can be triggered during and after the process of divorce, and an individual is "forced" to deal with them in order to integrate a new experience in his or her life.

According to some studies (Amato and Previti 2003, 603; Hewitt et al. $2006,1177)$ women are often those who initiate divorce, so our research focused on the female aspect of experiencing emotional changes in the post-divorce period in order to find out what emotional states and changes women face in the first years after divorce. Research (Gahler 2006) shows that in average, divorced women suffer more frequently from anxiety, depression, anger, and the feelings of incompetence, rejection and loneliness. They are more distressed and depressed than married or single women. According to several researchers (Amato 2000, 1274; Hetherington and Kelly 2002, 49-51; Kitson 1992), however, not all emotional changes accompanying and following divorce are negative. As a result of divorce women often develop new talents, gain new awareness and improve self-confidence.

\section{Consequences of divorce in adults}

Consequences of divorce affect various areas of one's life; they are long-term or temporary and depend on several factors. Divorce affects socio-economic and financial status; especially for women and children the risk for poverty increases (Galarneau and Sturroch 1997, 198), because income after divorce is lower. Emotional distress increases, which also affects mental and physical health (Clarke-Stewart and Brentano 2006, 62-75; Lucas 2005, 945), social network may change (Gahler 2006), raising and custody over children become important (Amato 2010; Ganc 2015, 103-104). Divorced individuals experience more emotional distress and more negative emotions. 
Divorce, in general, brings a period of time marked by stress, instability, vulnerability, feelings of loneliness and distress related to identity, self-confidence, and lifestyle (Clarke-Stewart and Brentano 2006, 55-56; Hooyman 2008, 261). Psychological well-being decreases (Amato 2010) and health issues lead to a greater risk for untimely death (Gahler 2006).

\section{Negative emotional changes}

Studies (Amato and Previti 2003, 603; Ganc 2015, 35-37; Williams and DunneBryant 2006, 1178) do not agree on how changes are perceived by men and women, respectively. According to some studies (Williams and Dunne-Bryant 2006, 1178), women experience more negative effects, while others (e.g. Amato 2000) show opposite results.

More than gender differences we should emphasize the fact that those who initiate divorce (Halperin 2006, 248) adapt more easily than those who are abandoned and older. It is noted that for women who are older and have less work experience, post-divorce period is typically more difficult than for younger women; their social network, which has proved important support at adaptation after divorce, is often smaller (Clarke-Stewart and Brentano 2006, 77-81; Lin 2007), and they get less support from their ex-husband with raising children.

The majority of women get child custody after divorce. This also applies for women in Slovenia (the Statistical Office of the Republic of Slovenia 2014), who together with custody get additional responsibilities regarding financial, physical and emotional care for their children. Professional demands and single-parent family chores cause additional distress to divorced women (Gahler 2006). The roles are often switched: sometimes women become main breadwinners and they carry heavier workload than men who have less contact with and chores related to children. Women experience anger and frustration due to their feelings of helplessness because their responsibilities surpass their capacities, and simultaneously they feel guilty because they do not spend enough time with their children (Clarke-Stewart and Brentano 2006, 71-72).

Problems related to child custody and raising and economic distress affect women's mood and health (Williams and Dunne-Bryant 2006, 1178): they experience more feelings of rejection, loneliness and anxiety and more often suffer from depression (Gahler 2006) and they have more health issues, although some authors ascribe more depressive symptoms to men after divorce.

For successful reorganization of family life, the process of facing one's emotions is of paramount importance. 
The process of facing one's emotions accompanying divorce

Divorce usually causes a painful situation accompanied by intense and hurting emotions, including deep sadness, anger and guilt, which are natural responses to grieving (Clarke-Stewart and Brentano 2006, 54-56; Hooyman 2008, 621). Divorce equals loss: a loss of a partner, a social network, economic security, an image of a family and an ideal of love. Facing divorce and negative emotions begins with the process of grieving; in working through various emotions, responses and changes typical of each stage, an individual slowly gets used to loss and gradually tries to accept it.

As a general rule, in the grieving process an individual moves through five stages (Kübler-Ross 1966, 2005, 7-24): denial, anger, bargaining, depression and acceptance, which take varying lengths of time and interweave in various ways. People differ in responses to and regulation of these emotions; some do not experience all stages, and sequence and duration of each stage differ (Kübler-Ross 1966, 2005, 227-230). Stages of grieving, which are interconnected, are defined by several models (Kübler-Ross 1966, 2005; Walsh 2012, 68; Walsh and McGoldrick 1991, 28) as follows:

Shock and denial - Often the first response to loss is shock because it is difficult to accept what has happened (Walsh 2012, 68; Walsh and McGoldrick 1991, 50). For some people it is almost impossible to believe that the loss truly happened, or they completely deny reality, still searching for their spouse's attention.

Sadness - Deep sadness is one of the most typical characteristics of grieving process. Sadness can be accompanied by a feeling of emptiness, despair, yearning, deep loneliness, a lot of crying, and / or emotional instability (Margulies 2007, 19-21).

Guilt - A sense of guilt can emerge in connection with what was said (or not) and what was done (or not); one's thoughts are focused on the question if the relationship really couldn't have been saved (Amato and Previti 2003, 623). One accuses oneself for not having prevented the breakup of the marriage.

Anger and bargaining - A person is focused on ex-spouse, on oneself or on a third person (also on God or life) as a response to the injustice he / she feels was done to them.

Fear - The loss triggers concerns and fears, anxiety and feelings of helplessness, uncertainty about the future increases. 
Acceptance - At one point, one realizes that the loss really happened and cannot be undone. He / she stops trying to maintain the relationship.

Physical symptoms - Although grieving is an emotional process, it frequently includes physical symptoms, such as fatigue, headaches, loss of weight, etc. (Walsh 2012, 68).

Working through divorce is a highly individual process; however, adaptation period generally takes two to five years.

Positive emotional changes after divorce in women

Not all consequences of divorce are negative. Women develop new talents and obtain new skills, some continue with formal and non-formal education and work on their careers (Clarke-Stewart and Brentano 2006, 76-77). After divorce, a lot of women discover new sources of strength, they build new supportive relationships, and in some cases, especially when they left violent relationships, they get rid of fear. They learn how to be more independent, work on their personal growth, make progress as parents, improve their self-confidence (especially women) and interpersonal skills (especially men) (Clarke-Stewart and Brentano 2006, 7677; Simonič, Rahne Mandelj and Novšak 2013, 346-347).

Research (Amato and Hohmann-Marriott 2007, 635) has shown that individuals who came from highly conflicting marriages experienced positive feelings after divorce, while those coming from "comfortable" marriages experienced more dissatisfaction.

The findings of research show that the consequences of divorce are not the same for all adults and that many need substantial amounts of time to adapt.

\section{Methodology}

\section{Design and Sample}

The study included 8 women, who ranged in age from 31 to 48,6 months to 6 years after they divorced. Semi-structured interviews were conducted. The participants were asked to describe their experiences in their own words. Detailed questions were based on the following general questions:

- How would you describe your experience of divorce?

- Which emotions and feelings have you faced during the process of divorce and after? 
- What are the biggest changes you have noticed in the period after divorce?

We analyzed data using a constructivist grounded theory methodology. Interviews took in average 60 minutes. Anonymity for the participants was guaranteed, i.e. their data would be used in such a way that their identities would not be revealed.

We recorded the interviews and wrote transcripts. Then we coded entries according to a specific thought or emphasis. Open coding followed; we attributed concepts, chunked related concepts into categories and analyzed the characteristics of concepts and categories (Miles and Huberman 1994, 55-62). Two basic categories emerged: "negative emotional changes" and "positive emotional changes".

\section{Results}

All women included in the study were the initiators of divorce. Their decision had matured gradually, and it was made as a result after several months' thinking, not impulsively; in the context of such decision, they also took the responsibility for the consequences of divorce. All women said that they had actively worked on preserving their marriage, trying to get closer to their spouses and to establish different ways of communication, as well as suggesting to search for professional help; however, they were losing their hope that the spouse was truly willing to change anything.

Their motherhood was an important factor in making the decision for divorce. Above all, they had concerns about how divorce will affect their children and how they could protect the children against negative consequences of the breakup of the family.

After six months (or more) after divorce, women included in our study perceived negative as well as positive changes.

\section{Negative emotional changes}

For these women, divorce was painful; they experienced the end of the relationship as the loss of an ideal family, dreams and expectations about the permanence of marriage (It hurts that you are no more a family; The dreams of a safe home are shattered; Marriage becomes irrelevant). They did not connect the feelings of loss with their spouse (He has been gone long ago; One doesn't lose a person but everything that could be and that actually was there at the beginning - this hurts).

Divorce marked an end of a life period which was connected to their highest values; they had to end a significant part of their life. 
All participants in the study went through the grieving process which took up to several years, despite of their own decision to end the relationship. They were often surprised by negative emotional states after the marriage was officially over, since they had already experienced them prior to divorce, feeling that they had successfully processed these emotions.

In the months and years after divorce the women experienced many negative emotions such as guilt, sadness, anger and feelings of incompetence and loneliness.

The feeling of guilt was experienced quite frequently. Women accused themselves (Why is this happening to me, What have I done wrong, What 's wrong with me, How could I be so blind that I didn't see the reality before we married) more frequently than their partners.

Anger was very obvious, too; they felt it especially intensely in the period when they informed the man about their decision. Anger emerged in the following contexts:

- His "seeming" change; they perceived their partner's willingness for a "radical change" in the relationship as solving his own distress and egotistic fulfilling his own needs also due to his fear to be left alone. An interviewee said: "Eight years I wasn't good enough for him, and now he would like to fix everything within a week, trying to be sweet and soft, trying to be somebody else. It's too late. Where was he six months ago?"

- His unwillingness to co-operate, now and in the future. They labelled this behaviour as a proof of irresponsibility and immaturity while he simultaneously seemingly tried to change (he was not ready to talk or create a mutual agreement about the splitting of property; he was passive, uninterested).

- His being inactive as a father; intense anger and sometimes contempt emerged when ex-spouse did not perform his fatherly role (He was no more a father; He behaved violently towards children; He was uninterested; He emotionally abused our child).

Some of the participants still had problems with their ex-husbands regarding custody and division of property, but after some time they handled stress resulting from these problems better than in the first few months after divorce.

Women also mentioned their economic and financial problems and their concerns regarding the future. Those who maintained their friendships and / or formed new social ties showed significantly better adjustment than those who remained socially isolated.

Positive emotional changes

The participants decided to divorce to achieve positive changes in their lives, and they had pondered their desires and needs and marital dissatisfaction several 
months prior to making the final decision to end their marriages. A majority told how this decision had matured with time, while in the case of marital violence after the birth of the first child, the decision was carried out immediately, without much deliberation and above all out of fear for life. In this case, a positive change was perceived in the very moment of physically moving away from the partner (relief, security).

With all women, the outlines of positive emotional changes started to show already at the stage of grieving; some women emphasized the following:

- A feeling of relief (the shift happened when they verbalized their decision; they were relieved due to available social sources of help - friends, professional services; relief because the partner had no more expectations; no more anguished atmosphere).

- A sense of freedom (Immediately after divorce I felt freedom; I was like a bird in a golden cage and now I' $m$ free).

- A feeling of happiness / pride (I was able to stand up for myself; I risked even the relationship with my parents, where there was a possibility they would reject me if I divorced).

After the "acceptance" stage, the women found a certain amount of peace within. They changed identity and developed some talents (During the grieving I was asking myself, "Who am I, what do I really want, am I really such a bad person, what would I like to become, what would I like to do with my life; I was learning about myself; I found myself), when they could start to enjoy hobbies for which there was no room within their marriages (I started to play guitar again - he never liked it).

They mentioned self-discovery (My needs have only become legitimate now, although one thinks about that before). They experienced feelings they had longed for in their marriages. (Now I can afford to really live as I want, although all the rest is difficult; Now I have what I missed emotionally).

They also felt changes as mothers (My daughter sees how I am happier, more content, and tells me how sad I used to be; My children are more relaxed than before, in a never-ending conflict; I raise my child in peace and without fear that he would beat us).

All participants, however, said that in spite of positive changes they would have wanted their marriages to succeed, so that they would not have been forced to take this life decision.

\section{Discussion}

Divorce brings fundamental re-organization of the lives of those involved, which in the first stage triggers negative emotional changes (Hooyman 2008, 261), 
which also applied for our participants, adapting to the new situation in the time of the study.

We found out that women were trying to make sense of their experience of divorce. For them, facing a loss meant dealing with a whole range of emotions, among which guilt and anger were especially striking. Guilt was exhibited as self-blame, and anger resulted from partner's reactions, such as him being too reluctant to work on the relationship, his uncooperative attitude regarding future and inadequate behavior to children. The grieving process, which came as a surprise, evolved in the context of ending a part of life and its duration varied among participants.

The study confirmed that negative changes are related to financial concerns and professional and household workload (Wallerstein and Kelly 1996, 108).

We realized that many women do not make a decision do divorce impulsively; rather, their decision is formed on the basis of reflection about their own desires and their children's needs, which perhaps prevails even in a situation when separation, due to safety, happens in a moment. In the case of violence between the two partners, where physical and emotional safety of either adults or children was no more guaranteed, divorce acts as protection, which is in accordance with Amato's (2000) findings about divorce as a positive action. Children are therefore a major factor in the decision for divorce.

In spite of the fact that these women initiated separation, they perceived divorce as a painful experience which, however, was a learning moment from which they emerged more personally mature, more self-confident, calmer and with more positive experiences. In the process of transition, people are open to change (Mezirow 2000, 22). They can change their identity (Illeris 2014, 90).

It was confirmed that during the process of divorce and immediately after it, there are more negative emotional changes, which women process in their relationships with their social network. The latter proved a significant source of help and support during adaptation to a new life situation (Hetherington and Kelly 2002, 77-78).

We found out that in spite of difficult transition due to psychological and physical burdens, positive changes are noticed as soon as in first months after divorce, in the feelings of relief, pride and freedom, while more prominent positive experiences emerge with time. With more functional lifestyles and the introduction of a new rhythm in their lives, the women developed talents and skills in different areas (career, parenthood). It should be emphasized that changes do not come independently: a woman needs to make a decision to change her life and to start acting on this decision (Hetherington and Kelly 2002, 68).

The conclusions of this study are therefore in accordance with the findings of other studies (Amato 2000, 1274; Williams and Dunne-Bryant 2006, 1178) 
that women experience both negative as well as positive changes after divorce. Positive changes which show after some time do not mean, however, that their efforts were not primarily devoted to preserving their marriage, and do not make up for the regret that they failed. Nobody marries in order to divorce; rather, people believe their marriage will last "till death do us part."

\section{Limitations of the study and recommendations for further research}

The results obtained are only valid for this study. The method of obtaining data and a small sample which only included women who were willing to participate in the study do not allow for generalizing of results. A question arises what answers we would get in cases where participants were at the beginning of the divorce process, or if a sample included a wider female population or women who had not initiate divorce. Another limitation of the study is linked to the question how willing / able individuals are to verbalize changes, reflect and perceive them, and whether answers would have been different had questions been asked in a different way.

Further research could focus on both genders and include divorcees who were abandoned or did not want to divorce; ex-partners could be included so we could compare different perception of change between them. Other dimensions of changes as well as changes related to various circumstances could be observed (e.g. the changes in people coming from highly conflicted marriages vs. those with a lesser degree of conflict). Research could be repeated after certain time so that the durability of changes would be examined.

\section{Conclusion}

Divorce is a painful experience for everyone involved, regardless of different outcomes. In spite of the conclusion that not all changes after divorce are negative - since divorce is also an opportunity for positive changes not only in the cases of violence, abuse and addictions within a family but also with individuals who decided to leave a marriage due to other reasons - it seems valid to emphasize stressful and difficult feelings accompanying adaptation to a new situation. Therefore results despite the limitations of the study can help in creating preventive educative, consulting and psychotherapeutic programmes which are important support in building and maintaining interpersonal relationships and divorce prevention. 


\section{References}

Amato, Paul R. 2000. The consequences of divorce for adults and children. Journal of Marriage and the Family 62:1269-87.

Amato, Paul R. 2010. Research on divorce: Continuing trends and new developments. Journal of Marriage and Family 72:650-666.

Amato, Paul R. and Alan Booth. 1991. Consequences of parental divorce and marital unhappiness for adult well-being. Social Forces 69:895-914.

Amato, Paul R. and Bryndl Hohmann-Marriott. 2007. A comparison of high-and low-distress marriages that end in divorce. Journal of Marriage and Family 69:621-638.

Amato, Paul R. and Denise Previti. 2003. People's reasons for divorcing: gender, social class, the life course, and adjustment. Journal of Family Issues 24: 602-626.

Clarke-Stewart, Alison and Cornelia Brentano. 2006. Divorce: Causes and consequences. New Haven, CT: Yale University Press.

Gahler, Michael. 2006. To divorce is to die a bit: a longitudinal study of marital disrupt and psychological distress among Swedish women and men. The Family Journal Counseling and Therapy for Couples and Families 14:372-82.

Galarneau, Diane and Jim, Sturroch. 1997. Family income after separation. Perspectives on labour and Income 9:18-28.

Ganc, Damijan. 2015. Izzivi očetovstva po ločitvi, (Zbirka Medosebni izzivi, 1). Sevnica: Družinski inštitut Zaupanje.

Halperin, Sandra M. 2006. Family therapy for the postdivorce adjustment of women left by their husbands for another woman. In: Craig, Everett A. and Robert E. Lee ed. When marriages fail, 247-259. New York, London, Oxford: The Haworth Press.

Hewitt, Belinda, Mark Western and Janeen Baxter. 2006. Who decides? The Social Characteristics Who Initiates Marital Separation. Journal of Marriage and Family 68:1165-1177.

Hetherington, Mavis E. and John Kelly. 2002. For better or for worse: Divorce reconsidered. New York: Norton.

Hooyman, Nancy. 2008. Living Through Loss: Interventions Across the Life Span. New York: Columbia University Press.

Holmes, Thomas and Richard Rahe. 1967. Holmes and Rahe stress scale. Retrieved from http://en.wikipedia.org/wiki/Holmes_and_Rahe_stress_scale.

Kitson, Gay C. 1992. Portrait of divorce: Adjustment to marital breakdown. New York: Guilford.

Kessler, Sheila. 1975. The American way of divorce: Prescriptions for change. Chicago: Nelson-Hall.

Kübler-Ross, Elisabeth. 1966, 2005. On grief and grieving: Finding the meaning of grief through the five stages of loss. New York: Simon \& Schuster Ltd.

Illeris, Knud. 2014. Transformative learning and identity. New York: Routledge.

Lucas, Richard E. 2005. Time does not heal all wounds: A longitudinal study of reaction and adaptation to divorce. Psychological Science 16:945-950. 
Margulies, Sam. 2007. Working with divorcing spouses: How to help clients navigate the emotional and legal minefield. New York: Guilford Press.

Miles, Matthew B. and Michael A. Huberman. 1994. Qualitative data analysis. Thousand Oaks, CA: Sage.

Mezirow, Jack. 2000. Learning as transformation: Critical perspectives on a theory in progress. San Francisco, CA: John Wiley \& Sons, Inc.

Simonič, Barbara, Tina Rahne Mandelj and Rachel Novšak. 2013. Religious-related abuse in the family. Journal of family violence 28:339-349.

Statistical Office the Republic of Slovenia (2014). Sklenitve in razveze zakonskih zvez, Slovenija, 2014 -končni podatki. [ Marriages and divorces, Slovenia, 2014 -final data.] Retrived from http://www.stat.si/StatWeb/glavnanavigacija/podatki/prikazistaronovico? IdNovice=6303.

Wallerstein, Judith S. and Joan B. Kelly. 1996. Surviving the breakup: How children and parents cope with divorce. New York: Basic Books.

Wallerstein, Judith, Julia M. Lewis and Sandra Blakeslee. 2000. The unexpected legacy of divorce: A 25-year landmark study. New York: Hyperion.

Walsh, Froma and Monica McGoldrick. 1991. Living beyond loss: Death in the family. New York, London: W.W. Norton \& Company.

Walsh, Katherine. 2012. Grief and loss. Theories and skills for the helping professions. Boston: Pearson.

Williams, Kristi and Alexandra Dunne-Bryant. 2006. Divorce and adult psychological well-being: Clarifying the role of gender and child age. Journal of Marriage and Family 68:1178-1196. 